\title{
Alterations in Adiposity and Glucose Homeostasis in Adult Gasp-1 Overexpressing Mice
}

\author{
Luce Périè Alexis Parenté Fabienne Baraige Laetitia Magnol \\ Véronique Blanquet \\ University of Limoges, INRA, UMR 1061, UGMA, Limoges, France
}

\section{Key Words}

Gasp-1 1 Glucose homeostasis $・$ Insulin resistance $\cdot$ Myostatin $•$ Aging

\begin{abstract}
Background/Aims: Myostatin is known as a powerful negative regulator of muscle growth playing a key role in skeletal muscle homeostasis. Recent studies revealed that myostatindeficient mice lead to an increase of insulin sensitivity, a decrease of adiposity and a resistance to obesity, showing that myostatin can also impact on metabolism. Thus, myostatin appeared as a potential therapeutic target to treat insulin resistance. Methods: We generated transgenic mice overexpressing Gasp-1, a myostatin inhibitor. Results: Surprisingly, we found that these mice gained weight with age due to an increase in fat mass associated with ectopic fat accumulation. In addition, these mice developed an adipocyte hypertrophy, hyperglycemia, hyperinsulinemia, muscle and hepatic insulin resistance. Understanding the molecular networks controlling this insulin resistance responsiveness in overexpressing Gasp-1 mice is essential. Molecular analyses revealed a deregulation of adipokines and muscle cytokines expression, but also an increase in plasma myostatin levels. The increase in myostatin bioactivity by a positive feedback mechanism in the $\mathrm{Tg}(\mathrm{Gasp}-1)$ transgenic mice could lead to this combination of phenotypes. Conclusion: Altogether, these data suggested that overexpressing Gasp-1 mice develop most of the symptoms associated with metabolic syndrome and could be a relevant
\end{abstract} model for the study of obesity or type 2 diabetes.

\section{Introduction}

The Transforming Growth Factor $\beta$ (TGF- $\beta$ ) superfamily members are essential regulators of diverse developmental and homeostatic processes in vertebrates and invertebrates including proliferation, growth, differentiation, migration, and death, as well as physiological processes such as wound healing, and muscle regeneration [1]. More than thirty closely related proteins form this superfamily which can be divided into two main functional groups, the TGF $\beta$-like group that induces the receptor-regulated SMAD transcription factors 2 and 3 and the Bone Morphogenetic Proteins (BMP)-like group activating the R-Smads 1, 5 and $8[2]$.

L. Périè and A. Parenté contributed equally to this work. 
Mutations or alterations in the expression of components of these signaling pathways have been associated with a wide range of human pathologies such as cancer, cardiovascular or muscle disorders $[3,4]$. Therefore, several TGF- $\beta$ members have frequently been assessed as diagnostic or prognostic markers and are also remarkable targets for drug development [5-7]. TGF- $\beta$ superfamily signaling is not limited to Smad-mediated pathways, as they can also mediate signaling responses through non-Smad pathways, in particular the Mitogen Activated Protein Kinase (MAPK) pathways, including Extracellular-signal-Regulated Kinase (ERK), p38, and Jun N-terminal Kinase (JNK); the Phosphoinositide 3-Kinase (PI3K)/Akt pathway, and the NF- $\kappa \mathrm{B}$ pathway with a crosstalk between canonical and non-canonical TGF- $\beta$ pathways.

Myostatin (MSTN), also named Growth and Differentiation Factor-8, signals through the TGF- $\beta$ branch and acts as a powerful negative regulator of muscle growth and plays a key role in skeletal muscle homeostasis. Loss-of-function mutations of the myostatin gene cause in different species increase of skeletal muscle mass resulting from a combination of muscle fiber hypertrophy and hyperplasia [8-11] while myostatin overexpression is associated with dramatic muscle atrophy in mice and lower skeletal muscle mass in male transgenic mice with muscle-specific overexpression of myostatin $[12,13]$.

In addition to its roles in skeletal muscle growth, many in vivo and in vitro studies have reported that MSTN also regulates metabolism by effects on muscle as well as on other metabolic sites such as adipose tissue or liver. The $M s t n^{-}$mice have a significant reduction in fat accumulation, an increase of insulin sensitivity on both standard chow and high fat diet (HFD). As Guo et al. reported, Mstn $\%$ mice have increased carbohydrate utilization for energy but the overall lipid utilization per animal did not change [14]. These mice have improved glucose and insulin tolerance and reduced blood glucose and insulin levels [14]. In a hyperinsulinemic-euglycemic clamp study, myostatin deficient mice have increased whole body glucose utilization rate with increases in glucose utilization by white and brown adipose tissue. Treatment with a myostatin antagonist also increased insulin sensitivity during HFD and a resistance to obesity [14-20]. Interestingly, loss of myostatin partially attenuates the obese and diabetic phenotypes of two mouse models of obesity and diabetes, agouti lethal yellow $\left(A^{y}\right)$ and obese $\left(L e p^{o b / o b}\right)[16,21-24]$.

Myostatin activity is mostly regulated by proper proteolytic processing as well as by extracellular inhibitors such as the myostatin propeptide, follistatin, follistatin like 3 (FSTL3), GASP-1 (Growth and Differentiation Factor-Associated Protein Serum 1) and GASP-2 [25-28]. Transgenic mice overexpressing follistatin or Fstl3 in skeletal muscle have increased skeletal muscle mass due to hypertrophy and hyperplasia and associated with a loss of global fat mass and adipose tissue $[29,30]$. Likewise, transgenic overexpression of myostatin propeptide at three months of age prevents diet-induced obesity and insulin resistance [24]. Altogether, these data would suggest that transgenic mice for which myostatin is inhibited or reduced present a resistance to diet induced obesity and are protected against the development of insulin resistance. But compared to these models, overexpressing Gasp-1 - Tg(Gasp-1) -mice present only a myofiber hypertrophy without hyperplasia and without a switch of fiber types [27, 31]. Using protein arrays on satellite cell derived myoblasts from Tg(Gasp-1) mice, we have shown an upregulation of myostatin associated with an activation ERK1/2 signaling pathway and a decrease of Pax7 expression, which could explain the absence of hyperplasia in our model [31]. Moreover, no significant loss of fat mass was observed in Tg(Gasp-1) [27]. To better understand this alteration in metabolism, we characterized in more details young and old $\mathrm{Tg}$ (Gasp-1) mice phenotypes. Unexpectedly, we showed that $\operatorname{Tg}$ (Gasp-1) animals gained weight with age due to an increase in fat mass associated with ectopic fat accumulation. In addition, $\operatorname{Tg}$ (Gasp-1) mice develop an adipocyte hypertrophy, hyperglycemia, hyperinsulinemia and an hepatic steatosis. We show that all these symptoms are linked to an insulin resistance developed by old $\operatorname{Tg}$ (Gasp-1) mice.

At the molecular level, we observed a decrease of the muscle-specific glucose transporter GLUT-4 and an upregulation of muscle proinflammatory muscle cytokines and adipokines. Altogether, these data show an insulin resistance phenotype in old $\operatorname{Tg}$ (Gasp-1) mice. Finally, 


\section{Cellular Physiology Cell Physiol Biochem 2017;44:1896-1911 \begin{tabular}{l|l|l} 
and Biochemistry 10.1159/000485878 & $\begin{array}{l}\text { C } 2017 \text { The Author(s). Published by S. Karger AG, Basel } \\
\text { www.karger.com/cpb }\end{array}$
\end{tabular}}

Périè et al.: Role of GASP-1 in Insulin Resistance Molecular Mechanisms

the upregulation of myostatin also found in old $\operatorname{Tg}($ Gasp-1) mice reveals that myostatin influences the metabolism of skeletal muscle, adipose tissue and liver, contributing to the development of a metabolic syndrome in old transgenic mice.

\section{Materials and Methods}

\section{Animals}

Transgenic mice overexpressing Gasp-1 - Tg(Gasp-1) were generated in our team as previously described [27]. Briefly, these mice present an ubiquitously overexpression of GASP-1 which leads to a hypermuscular phenotype. At 3 months of age, these mice present a muscle hypertrophy but no hyperplasia. All mice were bred and housed in the animal facility of University of Limoges under controlled conditions $\left(21^{\circ} \mathrm{C}, 12\right.$-h light/12-h dark cycle) with free access to standard mouse chow (RM1 (P) 801151, Special diets services, UK) and tap water. All analyses were realized with young (3-month-old) and old (16-month-old) mice, independently of animal sex.

\section{Phenotypic analyses}

To monitor body weight gain, animals were weighed once a week during 16 months. Body composition analysis to determine fat contents was performed on conscious young and old mice, using the EchoMRI-500 ${ }^{\mathrm{TM}}$ whole body composition analyzer (Echo Medical Systems). Before blooding sampling, WT and Tg(Gasp-1) mice were fasted $16 \mathrm{~h}$. Blood samples were collected in lithium heparin tubes under isofluorane anesthesia following the recommendations of ethical guidelines. At the collection day, blood samples were centrifuged at $4000 \mathrm{rpm}$ for $10 \mathrm{~min}$ and plasmas were harvested then analyzed on a KONELAB 30 automat as previously described [32].

Muscle and adipose tissue weights were measured following dissection of young and old mice. Individual muscles (tibialis anterior, gastrocnemius and soleus) from both sides of the animal were taken and the average weight was used for each muscle.

\section{Histological analyses}

Tissues (liver and inguinal adipose tissue) were collected from WT and Tg(Gasp-1) mice at different ages and fixed in formol for 3 days. Then, tissues were embedded in paraffin and sectioned with microtome in $4 \mu \mathrm{m}$ thickness. The sections were stained with hematoxylin and eosin. Measurements of area/size and quantification of adipocytes were realized with ImageJ software (http://rsbweb.nih.gov/ij/).

Oil Red 0 solution was prepared in propylene glycol $\left(5{\left.\mathrm{~g} . \mathrm{l}^{-1}\right)}\right.$ and heated at $100^{\circ} \mathrm{C}$ for $10 \mathrm{~min}$. Frozen liver were sectioned with a cryostat $\left(8 \mu \mathrm{m}\right.$ thick) and dried for $15 \mathrm{~min}$ at $37^{\circ} \mathrm{C}$. Sections were then fixed for 10 min in 10\% formol /PBS (v/v). To detect neutral lipid accumulation, sections were stained with Oil Red $\mathrm{O}$ for $10 \mathrm{~min}$ at RT and counterstained with hematoxylin for $2 \mathrm{~min}$ at RT.

\section{Immunofluorescence staining protocol}

Dissected skeletal muscles (tibialis anterior and gastrocnemius) were frozen in liquid nitrogen-cooled isopentane and stored $\mathrm{at}-80^{\circ} \mathrm{C}$ for further analysis or sectioned for immunostaining. The immunofluorescence staining protocol was optimized for GLUT-4 analysis in mouse skeletal muscle. Cryosections were thawed at room temperature, air-dried and fixed for $5 \mathrm{~min}$ in $75 \%$ acetone $25 \%$ ethanol. Subsequently sections were washed 3 times for 5 min in phosphate-buffered saline (PBS). Then, cryosections were blocked for 30 min in blocking buffer consisting of $10 \%$ goat serum (NGS, Invitrogen) and 1\% bovine serum albumin (BSA) in PBS, at room temperature. GLUT-4 antibody (rabbit IgG, Abcam) was applied to the sections at a dilution of 1:1000 in 5\% normal goat serum (NGS, Invitrogen) for $1 \mathrm{~h}$ at $37^{\circ} \mathrm{C}$. Following primary antibody incubation, sections were washed 3 times for $5 \mathrm{~min}$ in Tween-20 1\%/PBS. Secondary antibodies were applied to sections for $30 \mathrm{~min}$ at $37^{\circ} \mathrm{C}$ at a dilution of 1:2000 in PBS. GLUT-4 antibody was targeted with goat anti-rabbit IgG 488 (Invitrogen). DAPI (Sigma Aldrich) staining for cell nuclei was added to the secondary antibody at a $0.5 \mu \mathrm{g} \cdot \mathrm{mL}^{-1}$ concentration. After secondary antibody incubation, sections were washed 3 times for 5 min in Tween-20 1\%/PBS. We used the MetaMorph software (Molecular Devices, Sunnyvale, USA) to acquire images with a Leica DMI6000B inverted epifluorescence microscope and to determine the total intensity of GLUT-4 fluorescence for each image. 


\section{Cellular Physiology Cell Physiol Biochem 2017;44:1896-1911 \begin{tabular}{ll|l} 
DOI: 10.1159/000485878 & $\begin{array}{l}\text { O 2017 The Author(s). Published by S. Karger AG, Basel } \\
\text { wwww.karger.com/cpb }\end{array}$
\end{tabular} \\ Périè et al.: Role of GASP-1 in Insulin Resistance Molecular Mechanisms}

\section{Metabolic analyses}

For intraperitoneal glucose tolerance tests (IPGTTs), overnight-fasted mice were injected with $20 \%$ D-glucose ( 2 mg.g ${ }^{-1}$ body weight). Blood glucose levels were monitored using a glucose meter (Roche Applied Science) from $2.5 \mu \mathrm{l}$ of tail blood at 0, 15, 30, 60 and $120 \mathrm{~min}$ after glucose injection. Serum insulin levels were also measured after glucose injection in $10 \mu \mathrm{l}$ of serum from blood collected from the tip of the tail vein by sandwich ELISA (Rat/Mouse Insulin ELISA kit, Millipore). All measurements were performed in triplicate and data for the standard curve were fitted to a logistic plot with the MARS Data Analysis Software (BMG Labtech) to determine the levels of insulin.

\section{RNA isolation, retrotranscription and $q P C R$}

Total RNA from tissues (tibialis anterior, gastrocnemius, liver and inguinal adipose tissue) were isolated using RNeasy midi kit (Qiagen). Synthesis of cDNA was performed with the High Capacity cDNA Archive kit (Applied Biosystems) to convert $2 \mu \mathrm{g}$ of total RNA into single-stranded cDNA. Real-time quantitative PCR was performed on an ABI PRISM 7900 Sequence Detection System (Applied Biosystems) in triplicate using $20 \mathrm{ng}$ of cDNA. The total reaction volume of $17.5 \mu \mathrm{l}$ was made of $8.75 \mu \mathrm{l} 2 \times$ Master Mix SYBR Green (Applied Biosystems) and $300 \mathrm{nM}$ of primers (Table 1). Relative mRNA expression values were calculated by the $\Delta \Delta \mathrm{Ct}$ method with normalization of each sample to the average change in cycle threshold value of the controls.

Table 1. List of the primers used for SybrGreen analyses

\begin{tabular}{|c|c|c|c|}
\hline Genes & Primers & Sequences & GenBank \\
\hline G6pc & $\begin{array}{l}\text { G6pc-Fwd } \\
\text { G6pc-Rev }\end{array}$ & $\begin{array}{l}\text { CCTCGTCTTCAAGTGGATTCTGT } \\
\text { AAACACCGGAATCCATACGTTGGC }\end{array}$ & NM_008061 \\
\hline Pck1 & $\begin{array}{l}\text { Pck1-Fwd } \\
\text { Pck1-Rev }\end{array}$ & $\begin{array}{l}\text { GAACACAAGGGCAAGATCATC } \\
\text { TTGCCATCTTTGTCCTTCCG }\end{array}$ & NM_011044 \\
\hline Myh1 & $\begin{array}{l}\text { Myh1-Fwd } \\
\text { Myh1-Rev }\end{array}$ & $\begin{array}{l}\text { AAGCCGATGGGCATCTTCTC } \\
\text { GGACTTTCCAAGATGCTGCTC }\end{array}$ & NM_030679 \\
\hline Myh2 & $\begin{array}{l}\text { Myh2-Fwd } \\
\text { Myh2-Rev }\end{array}$ & $\begin{array}{l}\text { AATGCAGGGGACGCTGGAGGA } \\
\text { CATTCCTCACGGTCTTGGCG }\end{array}$ & NM_001039545 \\
\hline Myh4 & $\begin{array}{l}\text { Myh4-Fwd } \\
\text { Myh4-Rev }\end{array}$ & $\begin{array}{l}\text { TCTGGCACCACACCTTCTA } \\
\text { AGGCATACAGGGACAGCAC }\end{array}$ & NM_010855 \\
\hline Myh7 & $\begin{array}{l}\text { Myh7-Fwd } \\
\text { Myh7-Rev }\end{array}$ & $\begin{array}{l}\text { ACCTACTCGGGCCTCTTCTGC } \\
\text { AGGGGCCTCGCTCСTCTTCTT }\end{array}$ & NM_080728 \\
\hline Pgc1- $\alpha$ & $\begin{array}{l}\text { Pgc1- } \alpha-\text { Fwd } \\
\text { Pgc1- } \alpha-\text { Rev }\end{array}$ & $\begin{array}{l}\text { AAGTGTGGAACTCTCTGGAACTG } \\
\text { GGGTTATCTTGGTTGGCTTTATG }\end{array}$ & NM_008904 \\
\hline Fox01 & $\begin{array}{l}\text { Fox01-Fwd } \\
\text { Fox01-Rev }\end{array}$ & $\begin{array}{l}\text { GCGGGCAATTCAATTCGCCACAA } \\
\text { CAGCTCTTCTTCGGGGTGATTTT }\end{array}$ & NM_019739 \\
\hline Mstn & $\begin{array}{l}\text { Mstn-Fwd } \\
\text { Mstn-Rev }\end{array}$ & $\begin{array}{l}\text { CAGACCCGTCAAGACTCCTACA } \\
\text { ССТGCTTCACСАССТTCTTGA }\end{array}$ & NM_010834 \\
\hline $\mathrm{B} 2 \mathrm{~m}$ & $\begin{array}{l}\text { B2m-Fwd } \\
\text { B2m-Rev }\end{array}$ & $\begin{array}{c}\text { CAGTGCCTGGGCTCATGTCAAG } \\
\text { GTTCGGCTTCCCATTCTCC }\end{array}$ & NM_009735 \\
\hline$\beta$-actin & $\begin{array}{l}\beta \text {-actin-Fwd } \\
\beta \text {-actin-Rev }\end{array}$ & $\begin{array}{l}\text { TCTGGCACCACACСTTCTA } \\
\text { AGGCATACAGGGACAGCAC }\end{array}$ & NM_007393 \\
\hline Gapdh & $\begin{array}{l}\text { Gapdh-Fwd } \\
\text { Gapdh-Rev }\end{array}$ & $\begin{array}{l}\text { TGTGTCCGTCGTGGATCTGA } \\
\text { CCTGCTTCACCACСTTCTTGA }\end{array}$ & NM_008084 \\
\hline
\end{tabular}




\section{Cellular Physiology Cell Physiol Biochem 2017;44:1896-1911 \begin{tabular}{l|l} 
and Biochemistry Publishe.1159/000485878 & (c) 2017 The Author(s). Published by S. Karger AG, Basel \\
www.karger.com/cpb
\end{tabular} \\ Périè et al.: Role of GASP-1 in Insulin Resistance Molecular Mechanisms}

\section{Western blotting}

Tissues (tibialis anterior, gastrocnemius, pancreas, liver and inguinal adipose tissue) were crushed, centrifuged $\left(12,000 \times \mathrm{g}, 4^{\circ} \mathrm{C}, 20 \mathrm{~min}\right)$ and then lysed in a RIPA buffer (50 mM Tris, pH 8, $150 \mathrm{mM} \mathrm{NaCl}$, $0.1 \%$ SDS, $1 \%$ NP- $40,0.5 \%$ sodium deoxycholate, and protease inhibitors). Proteins were quantified at $A_{595 \mathrm{~nm}}$ using the Bradford assay (Bio-Rad). Equal amounts of proteins (50 $\mu \mathrm{g})$ were resolved on SDS-polyacrylamide gels (4-12\% gradient, Invitrogen) and then transferred onto $0.2 \mu \mathrm{m}$ nitrocellulose membranes. Membranes were then blocked using $5 \%$ non-fat dry milk (w/v) in TBST $0.1 \%$ buffer (50 mM Tris- $\mathrm{HCl}, 150 \mathrm{mM} \mathrm{NaCl}$, $\mathrm{pH} 7.4,0.1 \%$ Tween-20) for $1 \mathrm{~h}$ at room temperature, followed by incubation with specific primary antibodies overnight at $4^{\circ} \mathrm{C}$. Primary antibodies were used at a dilution of 1:1000 for anti-GLUT-4 (MAB1272, R\&D Systems) and for anti-GASP-1 (AF2070, R\&D Systems) and 1:2000 for anti-GAPDH (AF5718, R\&D Systems) antibodies. After 4 washes in TBST $0.1 \%(\mathrm{v} / \mathrm{v})$, membranes were incubated for $1 \mathrm{~h}$ at room temperature with 1:1000 dilution of secondary antibodies: anti-goat IgG horse-radish peroxidase (HRP) conjugate (P0449, Dako) or anti-mouse IgG HRP conjugate (P0447, Dako). After 4 more washes in TBST 0.1\% (v/v), immunoblots were developed by enhanced chemiluminescence. The developed films were analyzed using ImageQuant TL software (GE Healthcare). The graphs (densitometric analysis) were obtained using Image J software to quantify GLUT-4 signals normalized with GAPDH signals of three different experiments.

\section{Enzyme-linked immunosorbent assay (ELISA) of myostatin and insulin}

Myostatin and insulin concentrations for mouse plasmas were determined in a sandwich ELISA (GDF8/ Myostatin ELISA kit, R\&D Systems) and (RAT/Mouse Insulin Elisa, Millipore) as previously described [31]. All measurements were performed in triplicate and data for the standard curve were fitted to a logistic plot with the MARS Data Analysis Software (BMG Labtech) to determine the levels of myostatin and insulin.

\section{Cytokines and adipokines antibodies array}

Mouse cytokine array (Proteome Profiler Mouse Cytokine Array Kit, R\&D Systems) were used following the manufacturer's instructions on mouse tibialis anterior. Mouse Adipokine Array (Proteome Profiler Mouse Adipokine Array Kit, R\&D Systems) were used following the manufacturer's instructions on mouse inguinal adipose tissue. The arrays were incubated overnight at $4^{\circ} \mathrm{C}$ on a rocking platform shaker. The blots were detected using an enhanced chemiluminescence (BM Chemiluminescence Western Blotting Substrate (POD)) (Roche Applied Science) and exposed to a film (GE Healthcare Hyperfilm ECL, GE Healthcare). Densitometric analysis of the array image files were performed using ImageQuant TL software (GE Healthcare).

\section{Statistical analyses}

Unless otherwise stated, results are expressed as means \pm SEM. Two-way ANOVA was performed to examine the effect of genotype (wild type vs. Tg(Gasp-1)) and the effect of age (3 months-old vs. 16 monthsold) on each parameter. Statistical significance was set at $\mathrm{p}<0.05$. A minimum of three replicates were performed for each experimental condition.

\section{Results}

Overexpression of Gasp-1 leads to an increase of body weight and fat mass with age

The myostatin knockout mice phenotype, i.e. increase of muscle mass and reduced adipose tissue, do not vary with age [16]. As GASP-1 acts as an inhibitor of myostatin, we checked if age-related variations in $\operatorname{Tg}(\operatorname{Gasp}-1)$ phenotype occurs. First, we compared the body weight of wild type (WT) and $\operatorname{Tg}(\operatorname{Gasp}-1)$ mice at 3 and 16 months of age. While we observed that both genotypes took weight with aging, this increase was twice more important for aged $\operatorname{Tg}(G a s p-1)$ mice than WT (Fig. 1A-B). One hypothesis is that the body weight gain is related to an increase of global fat mass. Therefore, we calculated the percentage of fat mass of $\operatorname{Tg}$ (Gasp-1) mice compared to wild type (Fig. 1C). Only, an increase of fat mass was observed in old $\operatorname{Tg}(G a s p-1)$ mice. No significant difference was observed in young mice (Fig. 1C). We then tested if this fat mass increase is associated with an increase of muscle mass in old $\mathrm{Tg}($ Gasp-1). Three different muscles representative of each muscular metabolism: the 


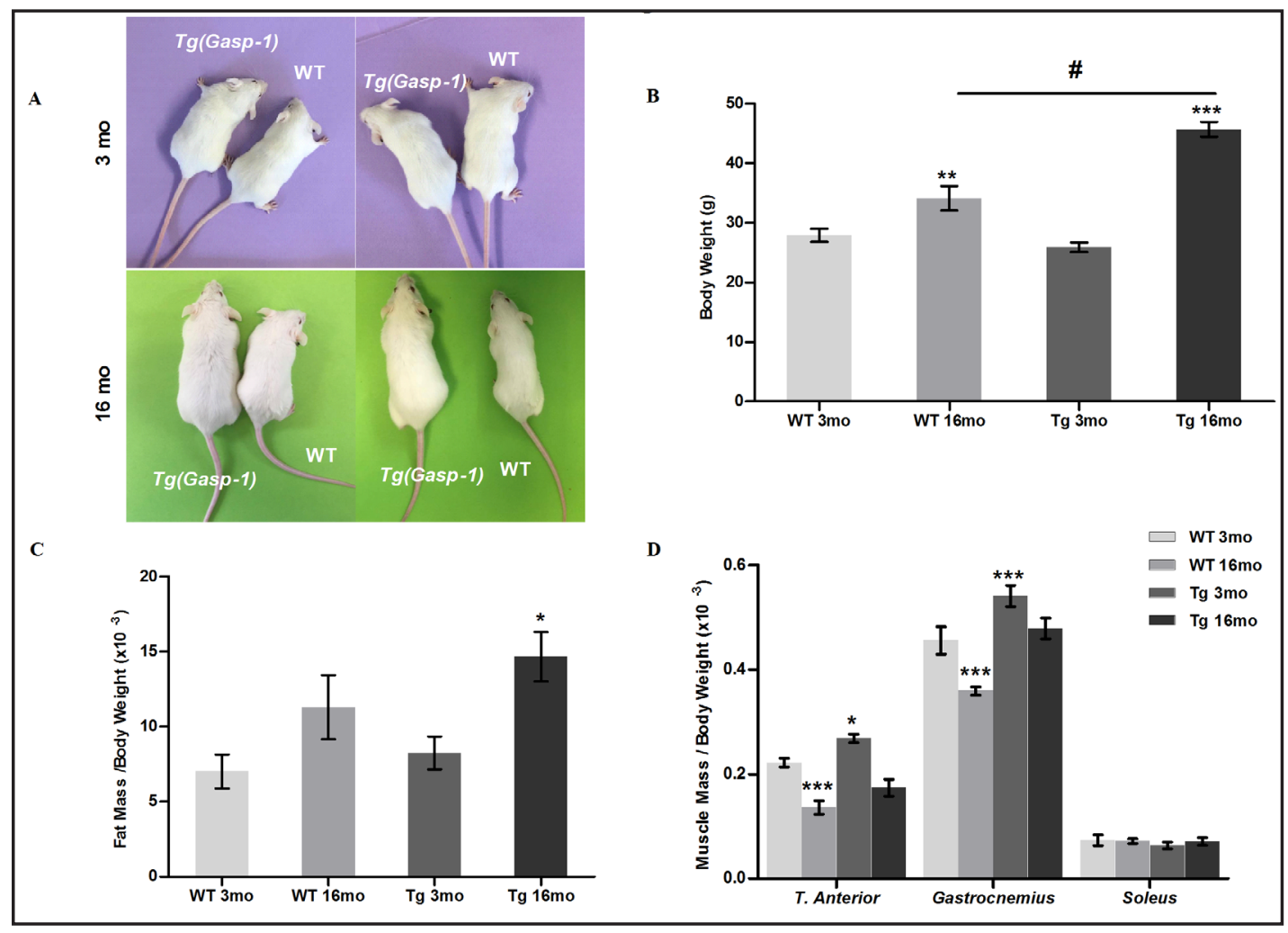

Fig. 1. Body weight, muscle and fat mass ratio in $\operatorname{Tg}$ (Gasp-1) mice. A. Morphological appearance of 3-month (upper panel) and 16-month- old (bottom panel) WT and overexpressing Gasp-1 mice, Tg(Gasp-1). B. Mean body weight. C. Fat mass/body weight ratio. D. Muscle mass/body weight ratio. Significance was assessed by comparing each sample with young WT mice in ANOVA statistical analysis (*: p value <0.05; **: p value $<0.005$; ***: p value < 0.001) and old Tg(Gasp-1) versus old WT mice (\#: p value < 0.05) (n=6 per group in all experiments). $\mathrm{Tg}: \operatorname{Tg}($ Gasp-1), T. anterior: tibialis anterior.

soleus (slow, oxidative), the tibialis anterior (fast, glycolytic), and the gastrocnemius (both oxidative and glycolytic myofibers) were used. As already shown in young $\mathrm{Tg}$ (Gasp-1) mice [27], we observed an increase about 10\% (tibialis) and 18\% (gastrocnemius) in Tg(Gasp-1) mice at 16 months of age. No variation was detected in soleus (Fig. 1D). We observed a decrease of muscle mass associated with aging in WT and transgenic mice but this effect is weaker in muscles of $\mathrm{Tg}$ (Gasp-1) mice still presenting the hypermuscular phenotype (Fig. 1D). To check whether any change in the expression of Gasp-1 occurred during aging, we measured mRNA levels in muscle of both genotypes. No significant difference of endogenous Gasp-1 was observed in WT mice. The overexpression of Gasp-1 was similar in both young and old $\operatorname{Tg}$ (Gasp-1) animals (Fig. 2A). Moreover, we showed that Gasp-1 overexpression is still found in liver and adipose tissue of old transgenic mice (Fig. 2B).

Fat mass accumulation is due to both WAT mass increase and ectopic fat deposition in liver

To determine the localization of the fat mass accumulation in old Tg(Gasp-1) mice, we analyzed the relative proportion of epididymal and inguinal masses, two white adipose tissues (WAT), compared to body weight (Fig. 3A). While the increase of WAT is observed in old wild type and mutant mice compared to young animals, the variation was more important in transgenic mice (Fig. 3A). Histological analyses revealed an increased adipocyte crosssectional area (CSA) in old Tg(Gasp-1) with a higher incidence of larger adipocytes compared to WT mice (Fig. 3B-D). In a lesser extent, this distribution was also slightly shifted towards larger adipocytes in young and old transgenic mice (Fig. 3C-D). Altogether, these results highlighted an adipocyte hypertrophy in $\mathrm{Tg}$ (Gasp-1) animals.

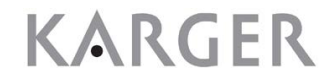


As liver tissue is capable of storing fat mass, we realized an Oil red 0 staining on liver frozen sections of young and aged WT and Tg(Gasp-1) mice (Fig. 4A). We observed extensive macrovesicular and microvesicular lipid in hepatocytes of old Tg(Gasp-1), and to a lesser extent in young mutant mice, revealing a hepatic steatosis (Fig. 4A). To check if the mice developed a hepatic necrosis too, the alanine aminotransferase (ALT C) and asparagine aminotransferase (AST C) enzymes activities were scored in both genotypes (Table 2). Aged transgenic mice present a significant higher level of ALT $\mathrm{C}$ and AST C enzymes (Table 2). These results underlined a global deregulation of fat storage with an increase of fat mass and ectopic fat deposition in aged $\operatorname{Tg}$ (Gasp-1) mice. It is well known that an insulin resistance phenotype is associated with an accumulation of triglycerides in liver. Therefore, we measured their levels in liver of young and old mice as well as cholesterol level. No variation of triglycerides and cholesterol levels was observed in young WT and Tg(Gasp-1) mice (Fig. 4B). However, a significant increase of triglycerides was detected in aged transgenic mice (Fig. 4B) highlighting an alteration of liver metabolism.

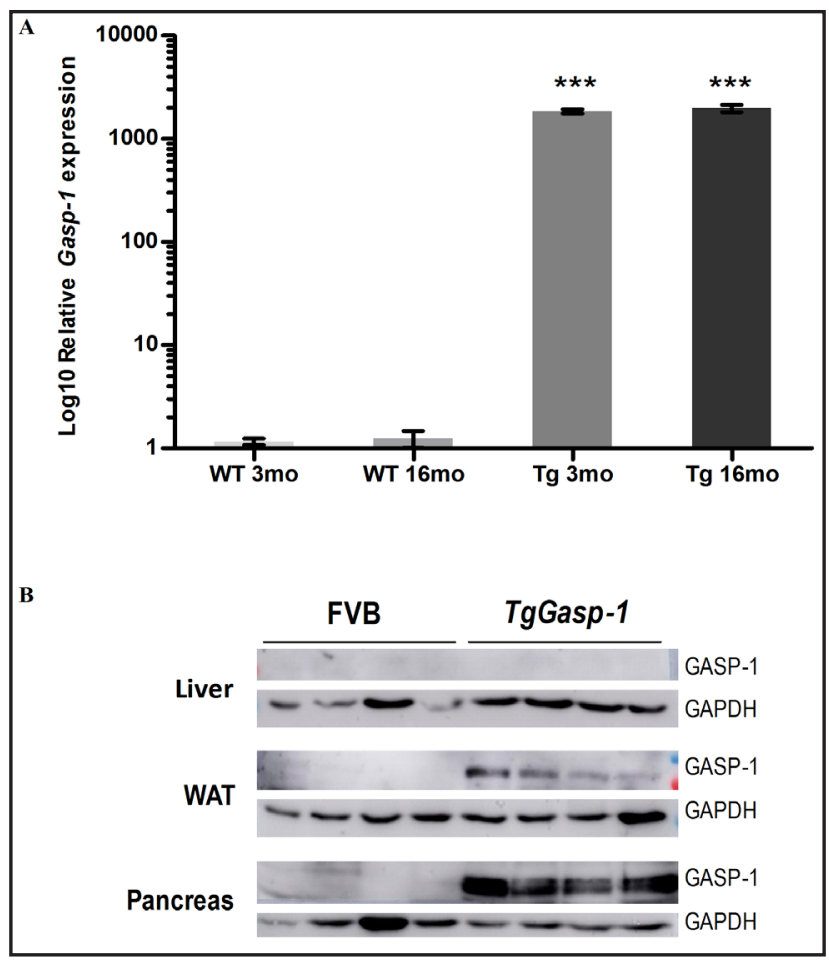

Fig. 2. Gasp-1 expression levels in old Tg(Gasp-1) mice. A. Relative mRNA expression levels of Gasp-1 were measured by quantitative PCR in tibialis anterior. Statistical significance was assessed by an ANOVA analysis when compared with the young WT mice $\left({ }^{* * *}\right.$ : p value $\left.<0.001\right)$. $(\mathrm{n}=6$ per group in all experiments). B. Western blot analysis of GASP-1 expression in old $\operatorname{Tg}$ (Gasp-1) mice. Total proteins were extracted from liver, pancreas and inguinal white adipose tissue (WAT) from 16-month-old WT and Tg(Gasp-1) mice. GASP-1 was detected using a polyclonal goat anti-GASP-1. Secondary HRP-anti-goat IgG was used for signal visualization with chemiluminescence. GAPDH was used as a loading control. $(n=4$ per group in all experiments). Tg: $\operatorname{Tg}($ Gasp-1).

\section{Old Tg(Gasp-1) mice develop an insulin resistance}

Metabolic syndrome is often associated to insulin resistance phenotype. To test this hypothesis, we performed the intraperitoneal glucose tolerance tests (IPGTTs) and monitoring the serum insulin level. No difference of glucose clearance and insulin sensitivity was observed between young WT and Tg(Gasp-1) mice (Fig. 5A-C). However, aged Tg(Gasp-1) mice cleared glucose much slower than WT mice at same age, indicating a glucose intolerance in the mutant mice (Fig. 5B). This glucose intolerance was accompanied by significantly elevated plasma insulin levels during the IPGTT confirming an insulin resistance in Tg (Gasp-1) mice (Fig. 5D). Altogether, these results assess a glucose homeostasis deregulation and an insulin resistance phenotype in old $\mathrm{Tg}$ (Gasp-1) mice.

\section{Deregulation of muscle and liver metabolism in Tg(Gasp-1) mice}

The insulin resistance can alterate glucose uptake and muscle metabolism. Thus, we analyzed the expression of the glucose transporter GLUT-4, which is regulated by insulin and found specifically in heart tissue, skeletal muscle, and adipose tissue. Western blot analysis revealed a decrease of 50\% of GLUT-4 expression in gastrocnemius muscle of old 


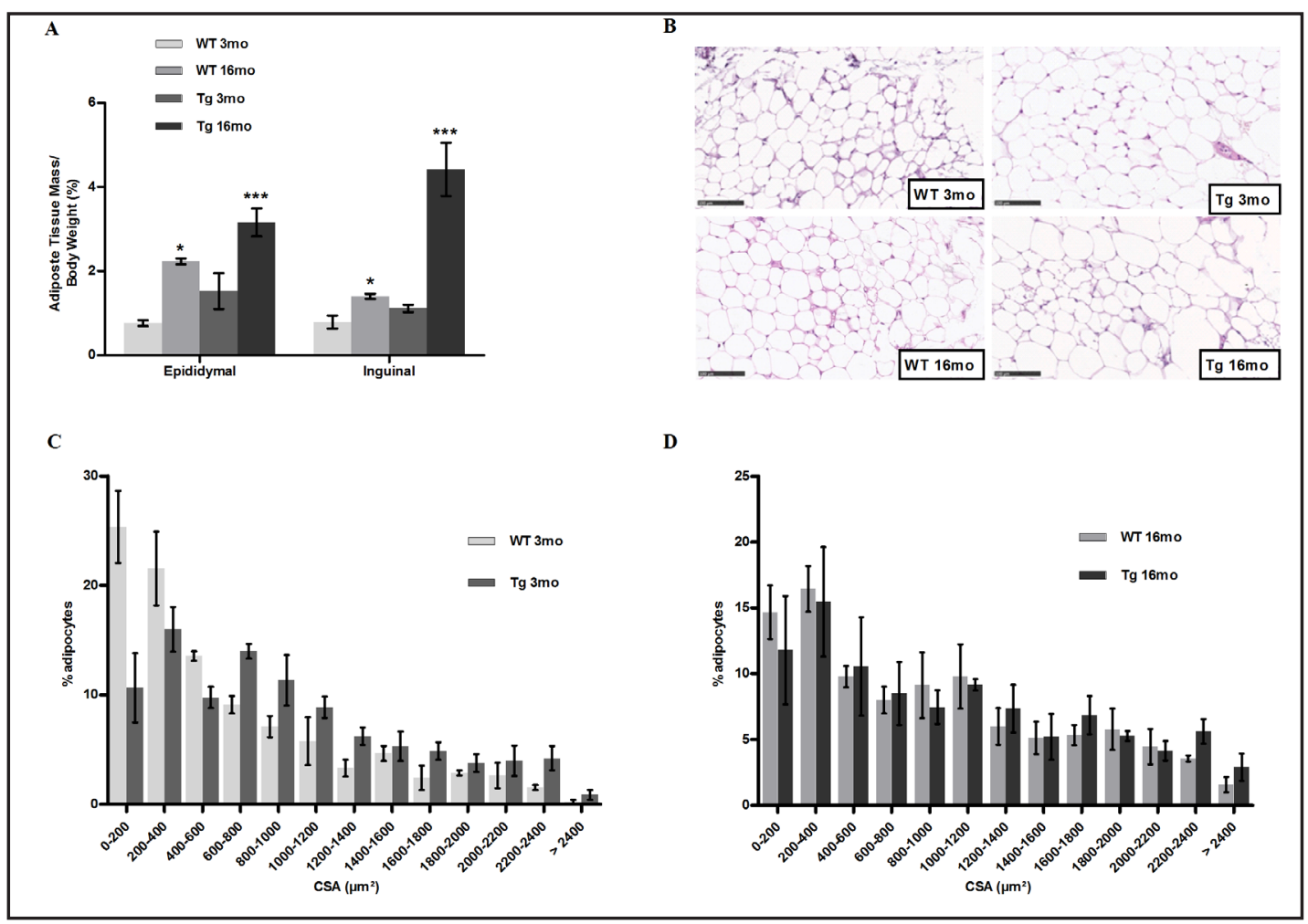

Fig. 3. Effect of Gasp-1 overexpression on fat mass. A. Relative proportion of epididymal and inguinal masses. B. Hematoxylin and eosin staining of inguinal adipose tissue sections. C-D. Distribution of adipocytes area in adipose tissue. Significance was assessed by comparing each sample with young WT mice in ANOVA statistical analysis (*: p value $<0.05$; ${ }^{* * *}$ : p value $\left.<0.001\right)$. ( $\mathrm{n}=6$ per group in all experiments). $\operatorname{Tg:~} \operatorname{Tg}(\operatorname{Gasp}-1)$.

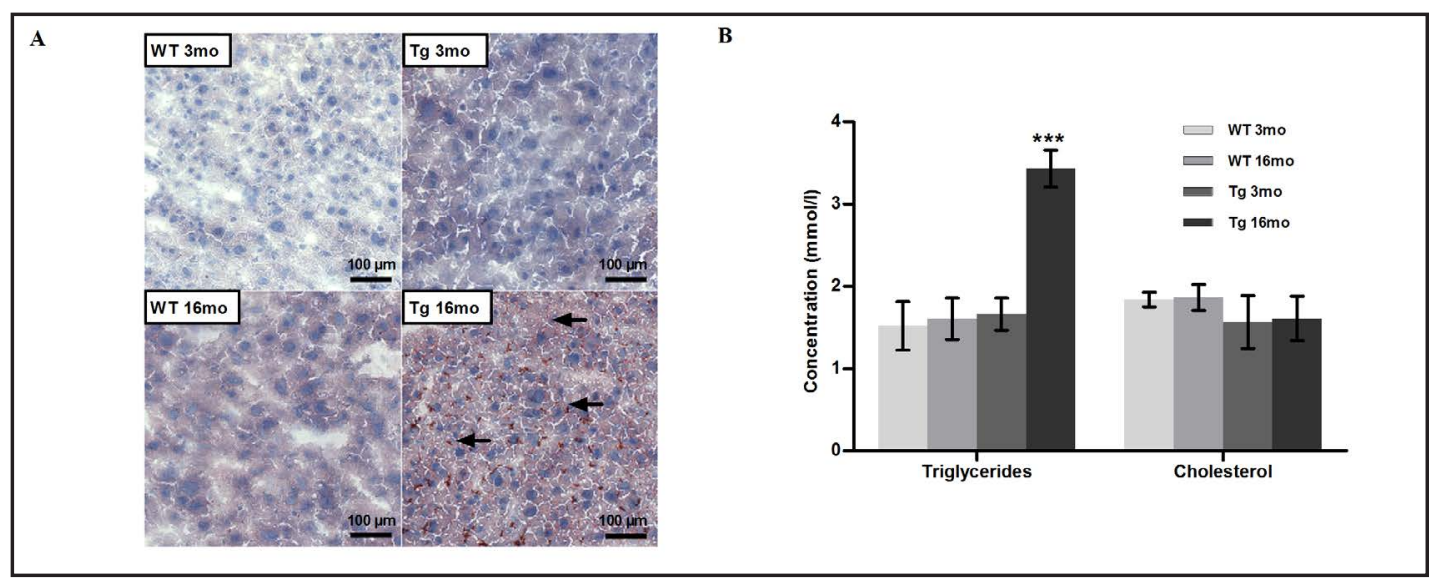

Fig. 4. Ectopic fat accumulation in liver of $\mathrm{Tg}$ (Gasp-1) mice. A. Oil Red and hematoxylin staining of frozen liver sections confirms vesicular steatosis (arrows). B. Triglycerides and cholesterol rates in liver. Significance was assessed by comparing each sample with young WT mice in ANOVA statistical analysis. $(* *$ : $\mathrm{p}$ value < 0.001). (n=6 per group in all experiments). Tg: $\operatorname{Tg}$ (Gasp-1).

Tg(Gasp-1) mice compared to WT regardless of age (Fig. 6A-B). It was confirmed by immunofluorescence, the total GLUT-4 fluorescence in basal condition decreased significatively in gastrocnemius of old Tg(Gasp-1) mice (Fig. 6C-D). Moreover, this analysis showed that GLUT4 seemed more accumulate in fibers rather that plasma membrane in $\operatorname{Tg}$ (Gasp-1) compared to WT mice (Fig. 6C). No difference was observed between young WT and Tg(Gasp-1) mice

\section{KARGER}


(data not shown). These data confirmed an alteration of muscle metabolism.

To go further, we decided to test if Pgc1 $\alpha$ and FoxO1, potent actors of muscle metabolism, were also altered by the insulin resistance. Thus, we quantified the expression level of these two genes. Pgc1 $\alpha$ expression was increased in young $\mathrm{Tg}$ (Gasp-1) mice compared to WT (Fig. 7A). In Tg(Gasp-1) mice, Pgc1 $\alpha$ expression was decreased at 16 months of age compared to young mice while no variation of FoxO1 expression was observed (Fig. 7A). Moreover, Pgc1 $\alpha$ and FoxO1 genes are essentially expressed in slow-type and fast-type myofibers respectively. The slow-type myofibers mostly express Myh7 and the fasttype myofibers express Myh2, Myh1 and Myh4. Q-PCR analyses on tibialis anterior show that young $\operatorname{Tg}$ (Gasp-1) mice present an upregulation of Myh7 compared to WT (Fig.

7B). Interestingly, Myh7 is drastically decreased in aged $\mathrm{Tg}$ (Gasp-1) mice compared to young transgenic mice (Fig. 7B).

The insulin resistance can also lead to modifications of liver metabolism. If insulin cannot act on liver, the gluconeogenesis gene expression should increase. We checked the expression of two key enzymes of this metabolic pathway, Phosphoenolpyruvate carboxykinase 1 (Pck1) and Glucose-6-Phosphatase (G6Pc). Pck1 expression was up-regulated by 3 -fold in aged $\mathrm{Tg}$ (Gasp-1) while a slight increase of G6Pc (1.5-fold) was observed (Fig. 7C). There was no significant variation of Pck1 and G6Pc expression in young mice (Fig. 7C). This result confirmed an elevation of hepatic gluconeogenesis which is associated to hepatic insulin resistance and contributes to hyperglycemia (Fig. 7D). These results showed the development of a metabolic syndrome with aging, responsible for the deregulation of glucose and fat homeostasis in $\mathrm{Tg}$ (Gasp-1) mice.

\section{Deregulation of adipokines and muscle cytokines expression in Tg(Gasp-1) mice}

The adipose tissue represents an active endocrine organ that releases a large number of bioactive mediators (adipokines) regulating fat mass and glucose homeostasis. To highlight the metabolic syndrome observed in aged $\operatorname{Tg}$ (Gasp-1), we analyzed adipokines expression in white adipose tissue. Out of 38 adipokines tested, eight were found upregulated in old mutant mice compared to WT at the same age. Old transgenic mice present a significant increase of C-Reactive Protein, ICAM-1 and Lipocalin-2 as well as growth factors, FGF acidic and HGF, TNF- $\alpha$, TIMP-1 and Serpin E1 (Fig 8A). All these overexpressed cytokines are often associated with insulin resistance phenotype. 


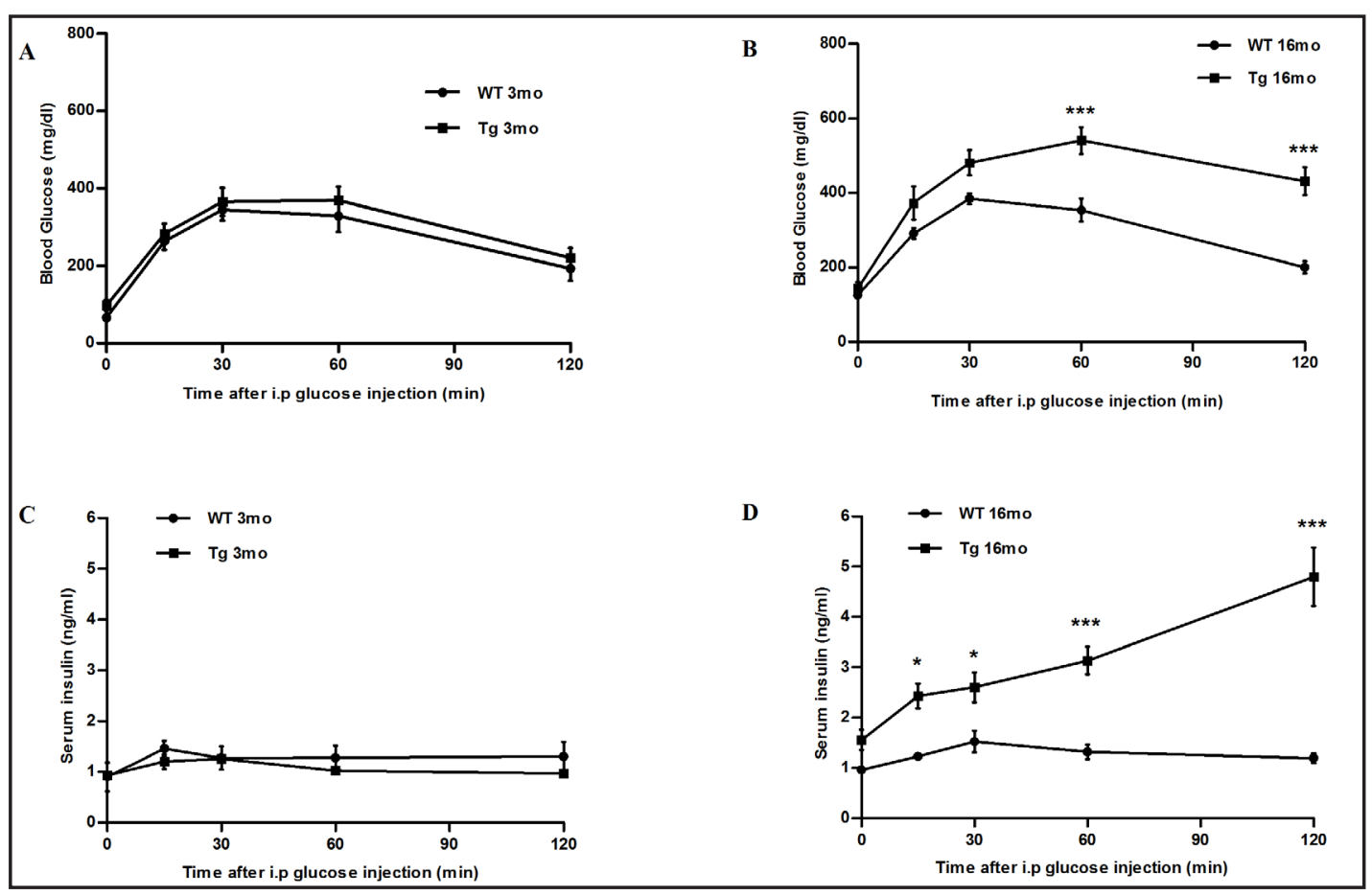

Fig. 5. Insulin resistance phenotype in Tg(Gasp-1) mice. A-B. (IPGTT) Overnight-fasted mice were injected with glucose (2 mg.g-1 body weight). Blood glucose levels were monitored at 0, 15, 30, 60 and 120 min after glucose injection of (A) 3-month and (B) 16-month-old mice. C-D. The serum level of insulin after glucose administration (i.p.) to mice was quantified by ELISA at 0, 15, 30, 60 and 120 min of (C) 3-month and (D) 16-month-old mice. *: p value < 0.05; ${ }^{* *}$ : $\mathrm{p}$ value $<0.001 ; \mathrm{n}=7$ per group in all experiments. $\operatorname{Tg:~} \operatorname{Tg}(\operatorname{Gasp}-1)$.

The same study was realized in skeletal muscle which can also participate in glucose and fat homeostasis by secreting proinflammatory cytokines. $\mathrm{Tg}$ (Gasp-1) mice present a significant increase of TNF- $\alpha$, IP-10, the interleukins IL-23, IL-27 and the chemokine CCL5 and to a lesser extent the CXCL 1, 2, 11, 12, IL-17 and TIMP-1 (Fig. 8B).

One of the most cytokines studied in muscle is myostatin which is known to participate in muscle development and glucose metabolism. Our previous molecular analysis performed on young $\operatorname{Tg}($ Gasp-1) mice revealed an increase of myostatin expression responsible for the absence of hyperplasia [31]. We hypothesized that this upregulation of myostatin could also be implicated in the insulin resistance phenotype observed in old mutant mice. Therefore, we measured myostatin expression on tibialis anterior and found a myostatin expression increase by 5 -fold in old Tg(Gasp-1) mice compared to WT mice (Fig. 9A). In serum, this upregulation is also observed (Fig. 9B). Altogether, these data would suggest the existence of a crosstalk between muscle, adipose tissue and liver in old $\operatorname{Tg}$ (Gasp-1) mice responsible for the insulin resistance in which myostatin played a central role.

\section{Discussion}

Myostatin acts as a powerful negative regulator of muscle growth and plays a key role in skeletal muscle homeostasis [8]. Recent studies have shown that Mstn-/- mice leads to an increase of insulin sensitivity, a decrease of adiposity and a resistance to obesity, demonstrating that myostatin can also impact on metabolism $[14,15]$. In previous studies, we have shown that transgenic mice overexpressing Gasp-1, a myostatin inhibitor, present a muscle hypertrophy without hyperplasia but no loss of fat mass unlike Mstn-/- mice [27, 31]. To explore in more details the role of Gasp-1 on energetic metabolism, we characterized young and old overexpressing Gasp-1 mice phenotypes in comparison to young and old WT 


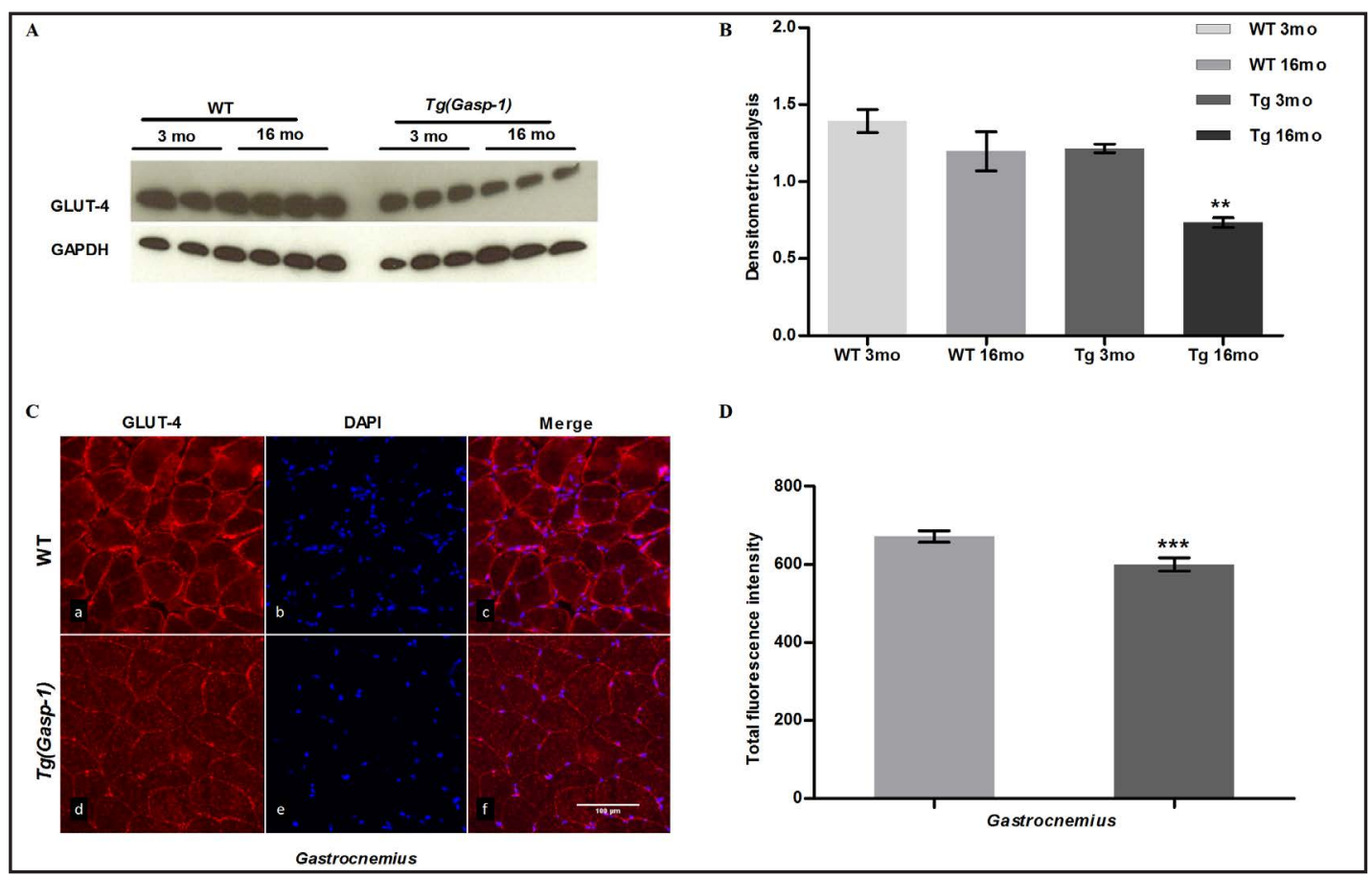

Fig. 6. Decrease of GLUT-4 expression in Tg(Gasp-1) mice. A-B. Western Blot analysis of GLUT-4. Total proteins extracted from gastrocnemius of WT and Tg(Gasp-1) mice were resolved by SDS-PAGE. Membranes were immunoblotted with anti-GLUT-4 antibody. Nitrocellulose membranes were also probed with anti-GAPDH antibodies to show equal loading. The graphs were obtained using Image J software to quantify GLUT-4 signal normalized with GAPDH signals of three different animals and experiments. C-D. Representative GLUT-4 immunofluorescence images of skeletal muscle of 16-month-old mice. GLUT-4 localization in gastrocnemius muscle ( $a$ and b), DAPI ( $b$ and e) and merge images (c and f) (scale bars $100 \mu \mathrm{m}$ ). C. The MetaMorph software was used to determine the total intensity of GLUT-4 fluorescence for each image. Significance was assessed by comparing each sample with young WT mice in ANOVA statistical analysis (**: $\mathrm{p}$ value $<0.005$; $^{* * *}$ : $\mathrm{p}$ value $\left.<0.005\right)$. ( $\mathrm{n}=7$ per group in all experiments). $\operatorname{Tg}$ : $\operatorname{Tg}$ (Gasp-1).

mice. First, we showed that the muscle hypertrophy observed at 3 months is still present in 16-month-old mice. In a unexpected way, we observed that $\operatorname{Tg}$ (Gasp-1) animals gained weight with age due to an increase in fat mass associated with ectopic fat accumulation compared to WT and independently of animal sex. This fat mass increase was not due to a feeding alteration. In addition, old $\operatorname{Tg}$ (Gasp-1) mice develop an adipocyte hypertrophy, hyperglycemia, hyperinsulinemia and an hepatic steatosis. We showed that these symptoms are linked to insulin resistance in old Tg(Gasp-1) mice. All these aging phenotypes are often associated with metabolic syndrome diseases like obesity or type II diabetes [33]. Since aging promotes phenotypes such as insulin resistance and glucose intolerance, we checked that the observed phenotype is not associated with an endogenous increase in Gasp-1 expression with age. No age-related Gasp-1 increase was found in wildtype mice. In addition, the GASP-1 overexpression remains similar in young and old $\operatorname{Tg}$ (Gasp-1) mice.

To understand this insulin resistance phenotype, we investigated the adipose tissue secretome. Indeed, deregulation of adipokines and more precisely inflammatory responses in adipose tissue have been shown as a major mechanism to induce insulin resistance. Several adipokines associated with metabolic syndrome were found increased in adipose tissue of old $T g$ (Gasp-1) mice like CRP, TIMP, HGF, TNF- $\alpha$, lipocalin-2, PAI-1 and FGF acidic [34-40]. CRP inhibits glucose uptake in muscle and liver and its increase could participate to the deregulation of glucose homeostasis, i.e. hyperglycemia, observed in $\operatorname{Tg}$ (Gasp-1) mice [41]. Similarly, TIMP and HGF known to increase adipocytes size and triglycerides levels in liver and increased size of pancreatic islets $[42,43]$ are also overexpressed in $\operatorname{Tg}($ Gasp-1)

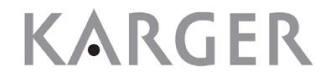




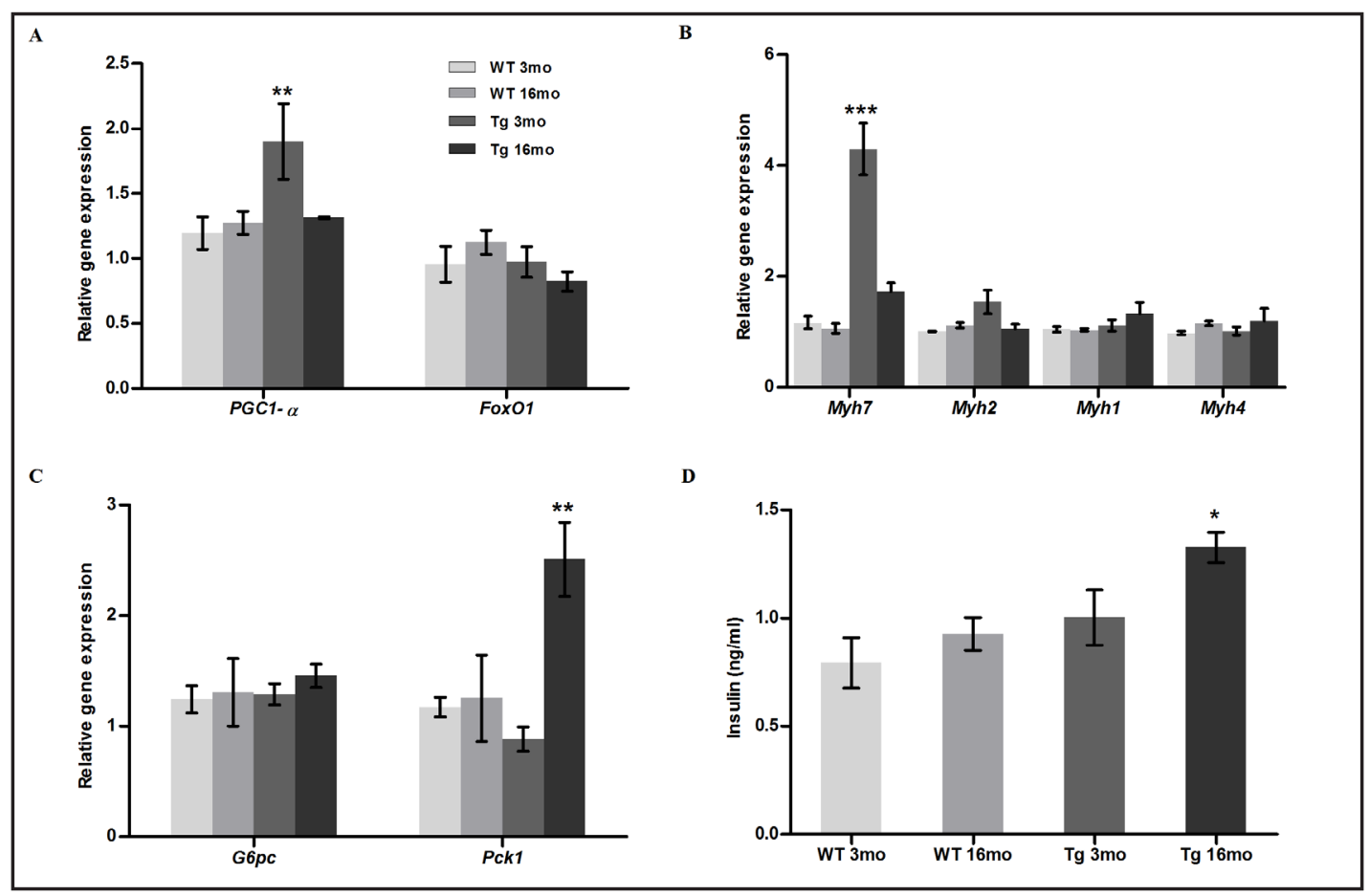

Fig. 7. Muscle and hepatic insulin resistance observed in $\mathrm{Tg}$ (Gasp-1) mice. A-B. Relative mRNA expression levels of (A) Pgc1- $\alpha$ and FoxO, (B) Myh7, Myh2, Myh4, Myh1 were measured by quantitative PCR in tibialis anterior. C. Relative mRNA expression levels of gluconeogenic genes (Pck1 and G6Pc) by quantitative PCR in liver. D. Insulin plasma levels. Significance was assessed by comparing each sample with young WT mice in ANOVA statistical analysis (*: p value $<0.05$; $^{* *}$ : $\mathrm{p}$ value $<0.005$; $^{* * *}$ : $\mathrm{p}$ value $\left.<0.001\right)$. $(\mathrm{n}=6$ per group in all experiments). Tg: $\operatorname{Tg}$ (Gasp-1).

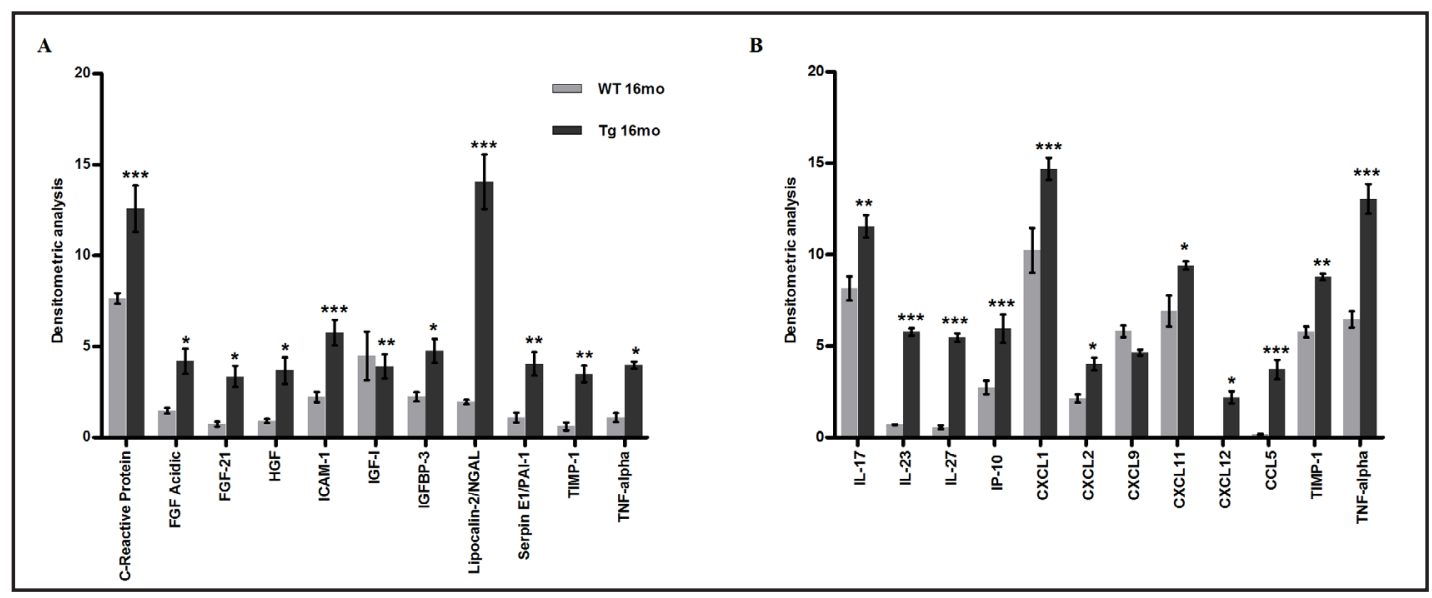

Fig. 8. Deregulation of adipokines and muscle cytokines expression in old Tg(Gasp-1) mice. A. Adipokine levels were measured in adipose tissue of 16-month-old mice and using the proteome adipokine array. B. Cytokine levels were measured in tibialis anterior of 16-month-old mice using the proteome cytokine array. The level of each cytokine was quantified by densitometry. *: p value $<0.05$; ${ }^{* *}$ : p value $<0.005$; ${ }^{* *}$ : $p$ value $<0.001 ; \mathrm{n}=5$ per group in all experiments. Tg: $\operatorname{Tg}$ (Gasp-1).

mice. Altogether, these findings suggested that in our transgenic mice, insulin resistance might result from the alteration of adipokines expression at least in part.

Many studies have shown that glucose homeostasis is regulated by a crosstalk between adipose and muscle tissue involving adipokines and muscle cytokines. To check this 


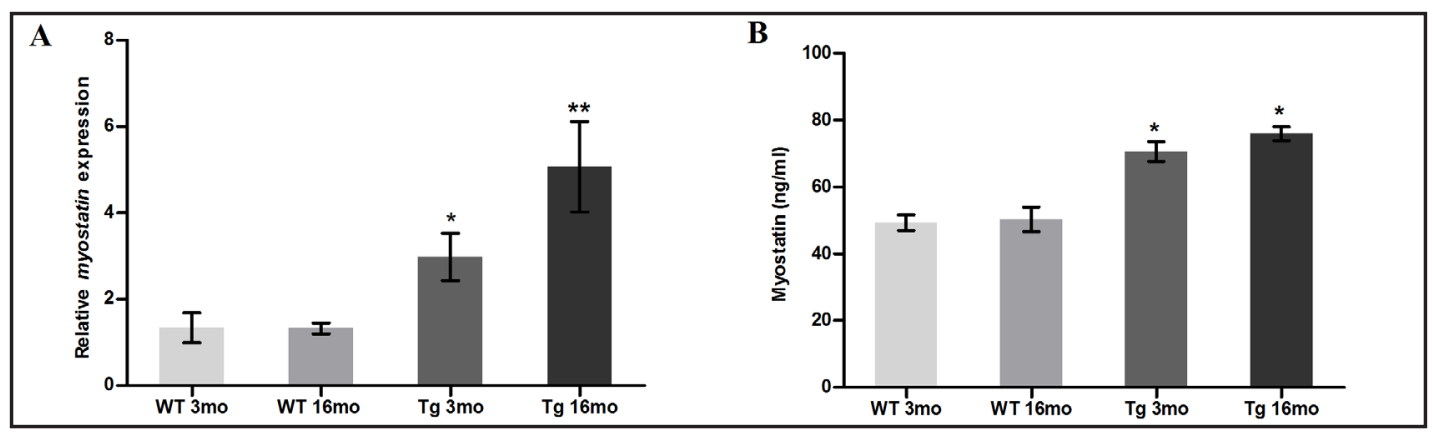

Fig. 9. Myostatin expression in muscles of Tg(Gasp-1) mice. A. Relative mRNA expression levels of myostatin were measured by quantitative PCR in tibialis anterior. B. Quantification of myostatin measured by an ELISA test. Significance was assessed by comparing each sample with young WT mice in ANOVA statistical analysis ${ }^{*}$ : $\mathrm{p}$ value $<0.05$; $^{* *}$ : p value $\left.<0.005\right)$. ( $\mathrm{n}=6$ per group in all experiments). $\mathrm{Tg}$ : $\operatorname{Tg}$ (Gasp-1).

potential crosstalk in $\mathrm{Tg}$ (Gasp-1) mice, we measured the expression level of a large number of muscle cytokines. We revealed an overexpression of proinflammatory cytokines on the one hand, and an increase of myostatin muscle expression and myostatin plasma levels on the other hand. To explain the muscle phenotype in $\operatorname{Tg}$ (Gasp-1) mice, we have already shown an upregulation of myostatin due to a positive feedback mechanism [31]. It is known that absence of myostatin leads to an increase of insulin sensitivity with a reduce of fat mass whereas the myostatin treatment induces an insulin resistance phenotype [44]. Therefore, the myostatin upregulation still present in old $\operatorname{Tg}($ Gasp-1) mice could be responsible for all of these metabolic phenotypes. Indeed, myostatin can inhibit GLUT-4, the muscle glucose transporter [45]. We found a GLUT-4 expression decrease in Tg(Gasp-1) muscle mice as well as an alteration of GLUT-4 membrane translocation, leading to an hyperglycemia. Furthermore, Pgc1 $\alpha$ expression which promotes mitochondrial biogenesis and lipid oxidation is negatively regulated by myostatin through AKT or AMPK signaling pathways [15, 46-48]. In Mstn knockout mice, absence of myostatin induced AMPK/Irisin/PGC1 $\alpha$ signaling pathway which improved insulin sensitivity and increased brown adipose tissue expansion [47, 48]. High levels of PGC1 $\alpha$ protein expression also promote a fast-to-slow switch fiber type identified by the expression of type I myosin heavy chain Myh7 [48-51]. In old Tg(Gasp-1) mice, the Pgc1 $\alpha$ expression decrease associated with a decrease of Myh7 expression showed a slowto-fast switch fiber type in these mice which confirmed the action of the deregulation of myostatin expression. Myostatin can also act indirectly on organs or tissues involved in glucose homeostasis by modulating the muscle secretome [19, 37]. For example, myostatin promotes the production of pro-inflammatory cytokines such as TNF- $\alpha$, PAI-1 or CXCL10 $[19,52]$. These two cytokines capable to induce an hepatic insulin resistance and pancreatic lipotoxicity are found overexpressed in $\operatorname{Tg}$ (Gasp-1) mice as in patients with metabolic disorders $[19,53]$. Interestingly, other cytokines are overexpressed in $\operatorname{Tg}($ Gasp-1) animals such the chemokines CXCL11, CXCL2, CCL12 which are regularly found overexpressed in obese or diabetic individuals $[33,53,54]$.

Finally, we cannot exclude a direct effect of Gasp-1 on glucose homeostasis since it is ubiquitously overexpressed in our transgenic mice [27]. Its expression is higher in $\operatorname{Tg}$ (Gasp-1) adipose tissue and pancreas compared to wild type mice. This overexpression could be responsible for the slight adipocyte hypertrophy observed in $\operatorname{Tg}(G a s p-1)$ and thus independently of its action of myostatin. To determine a potential role of Gasp-1 in adipocyte hypertrophy, we are currently generating a Gasp-1 overexpression model on a myostatin deficient background. In addition, as GASP-1 is a secreted protein, its overexpression could affect all the organs involved in glucose homeostasis.

GASP-1 is also known to antagonize GDF-11, another TGF- $\beta$ which promotes proliferation and differentiation of pancreatic islets [55]. The observed overexpression of Gasp-1 in pancreas could deregulate GDF-11 signaling pathway and disturb the function of 


\section{Cellular Physiology Cell Physiol Biochem 2017;44:1896-1911 \begin{tabular}{l|l|l} 
and Biochemistry Published online: December 08, 2017 & $\begin{array}{l}\text { (c) } 2017 \text { The Author(s). Published by S. Karger AG, Basel } \\
\text { www.karger.com/cpb }\end{array}$
\end{tabular}

this tissue. Finally, GASP-1 by its multiple protease inhibitors domains can also participate in the balance between protease and inhibitors highly regulated in pancreas to control the glucose homeostasis $[56,57]$. Treatment with recombinant protein GASP-1 on pancreatic cells will present a great interest to determine if Gasp-1 can act independently of myostatin on proliferation, differentiation and insulin secretion capacity of these cells. It would be also interesting to check if overexpression of Gasp-1 impacts on energy expenditure and fuel oxidation via age-dependent mechanisms.

Our data revealed that the upregulation of myostatin in overexpressing Gasp-1 mice has significant impact on glucose homeostasis and fat distribution. Aged Tg(Gasp-1) mice present several metabolic defects and could be a relevant model to study insulin resistance mechanisms. These results also demonstrate the complexity of crosstalk between tissues regulating glucose homeostasis and the difficulty to determine the primary tissue responsible from the alteration of glucose metabolism.

\section{Acknowledgements}

We are indebted to Dr. Brigitte Picard and Dr. Isabelle Cassar Malek for access to the EchoRMI-500TM analyzer. We also thank Karine Pasquier from the animal facility (SCA) for her technical help with animals.

All animal experiments were performed according to European directives (86/609/ CEE and 2010/63/UE) and approved by the Committee on Ethics of Animal Experiments from the Author's Institution, "Comité Régional d'Ethique de l'Expérimentation Animale" of the Limousin region ( $\left.\mathrm{n}^{\circ} 11-2014-11\right)$. According to the European Directive 210-63-EU, mice were observed daily for the general health status and mortality scoring.

This project was co-financed by the European Union, the Limousin Regional Council and the French National Institute for Agricultural Research. LP and AP were supported by a PhD fellowship from INRA/Region Limousin.

\section{Disclosure Statement}

The authors have nothing to disclose.

\section{References}

1 Wakefield LM, Hill CS: Beyond TGFbeta: roles of other TGFbeta superfamily members in cancer. Nat Rev Cancer 2013;13:328-341.

2 Shi Y, Massague J: Mechanisms of TGF-beta signaling from cell membrane to the nucleus. Cell 2003;113:685-700.

-3 Massague J, Blain SW, Lo RS: TGFbeta signaling in growth control, cancer, and heritable disorders. Cell 2000;103:295-309.

4 Gordon ES, Gordish Dressman HA, Hoffman EP: The genetics of muscle atrophy and growth: the impact and implications of polymorphisms in animals and humans. Int J Biochem Cell Biol 2005;37:2064-2074.

5 Burks TN, Cohn RD: Role of TGF-beta signaling in inherited and acquired myopathies. Skelet Muscle 2011;1:19.

-6 Akhurst RJ, Hata A: Targeting the TGFbeta signalling pathway in disease. Nat Rev Drug Discov 2012;11:790-811.

7 Neuzillet C, Tijeras-Raballand A, Cohen R, Cros J, Faivre S, Raymond E, de Gramont A: Targeting the TGFbeta pathway for cancer therapy. Pharmacol Ther 2015;147:22-31.

8 McPherron AC, Lee SJ: Double muscling in cattle due to mutations in the myostatin gene. Proc Natl Acad Sci U S A 1997;94:12457-12461.

-9 Grobet L, Martin LJ, Poncelet D, Pirottin D, Brouwers B, Riquet J, Schoeberlein A, Dunner S, Menissier F, Massabanda J, Fries R, Hanset R, Georges M: A deletion in the bovine myostatin gene causes the doublemuscled phenotype in cattle. Nat Genet 1997;17:71-74.

10 Kambadur R, Sharma M, Smith TP, Bass JJ: Mutations in myostatin (GDF8) in double-muscled Belgian Blue and Piedmontese cattle. Genome Res 1997;7:910-916.

11 Szabo G, Dallmann G, Muller G, Patthy L, Soller M, Varga L: A deletion in the myostatin gene causes the 


\section{Cellular Physiology Cell Physiol Biochem 2017;44:1896-1911 \begin{tabular}{l|l|l}
\hline and Biochemistry 10.1159/000485878 & $\begin{array}{l}\text { C } 2017 \text { The Author(s). Published by S. Karger AG, Basel } \\
\text { www.karger.com/cpb }\end{array}$ \\
\hline
\end{tabular}}

compact (Cmpt) hypermuscular mutation in mice. Mamm Genome 1998;9:671-672.

-12 Zimmers TA, Davies MV, Koniaris LG, Haynes P, Esquela AF, Tomkinson KN, McPherron AC, Wolfman NM, Lee SJ: Induction of cachexia in mice by systemically administered myostatin. Science 2002;296:14861488.

13 Reisz-Porszasz S, Bhasin S, Artaza JN, Shen R, Sinha-Hikim I, Hogue A, Fielder TJ, Gonzalez-Cadavid NF: Lower skeletal muscle mass in male transgenic mice with muscle-specific overexpression of myostatin. Am J Physiol Endocrinol Metab 2003;285:E876-888.

14 Guo T, Jou W, Chanturiya T, Portas J, Gavrilova O, McPherron AC: Myostatin inhibition in muscle, but not adipose tissue, decreases fat mass and improves insulin sensitivity. PLoS One 2009;4:e4937.

15 Zhang C, McFarlane C, Lokireddy S, Bonala S, Ge X, Masuda S, Gluckman PD, Sharma M, Kambadur R: Myostatin-deficient mice exhibit reduced insulin resistance through activating the AMP-activated protein kinase signalling pathway. Diabetologia 2011;54:1491-1501.

16 McPherron AC, Lee SJ: Suppression of body fat accumulation in myostatin-deficient mice. J Clin Invest 2002;109:595-601.

17 Elliott B, Renshaw D, Getting S, Mackenzie R: The central role of myostatin in skeletal muscle and whole body homeostasis. Acta Physiol (Oxf) 2012;205:324-340.

18 Feldman BJ, Streeper RS, Farese RV, Jr., Yamamoto KR: Myostatin modulates adipogenesis to generate adipocytes with favorable metabolic effects. Proc Natl Acad Sci U S A 2006;103:15675-15680.

19 Wilkes JJ, Lloyd DJ, Gekakis N: Loss-of-function mutation in myostatin reduces tumor necrosis factor alpha production and protects liver against obesity-induced insulin resistance. Diabetes 2009;58:1133-1143.

20 Hamrick MW, Pennington C, Webb CN, Isales CM: Resistance to body fat gain in 'double-muscled' mice fed a high-fat diet. Int J Obes (Lond) 2006;30:868-870.

-21 LeBrasseur NK, Schelhorn TM, Bernardo BL, Cosgrove PG, Loria PM, Brown TA: Myostatin inhibition enhances the effects of exercise on performance and metabolic outcomes in aged mice. J Gerontol A Biol Sci Med Sci 2009;64:940-948.

-22 Morissette MR, Stricker JC, Rosenberg MA, Buranasombati C, Levitan EB, Mittleman MA, Rosenzweig A: Effects of myostatin deletion in aging mice. Aging Cell 2009;8:573-583.

23 Tu P, Bhasin S, Hruz PW, Herbst KL, Castellani LW, Hua N, Hamilton JA, Guo W: Genetic disruption of myostatin reduces the development of proatherogenic dyslipidemia and atherogenic lesions in Ldlr null mice. Diabetes 2009;58:1739-1748.

24 Zhao B, Wall RJ, Yang J: Transgenic expression of myostatin propeptide prevents diet-induced obesity and insulin resistance. Biochem Biophys Res Commun 2005;337:248-255.

25 Lee SJ, McPherron AC: Regulation of myostatin activity and muscle growth. Proc Natl Acad Sci U S A 2001;98:9306-9311.

26 Lee SJ: Quadrupling muscle mass in mice by targeting TGF-beta signaling pathways. PLoS One 2007;2:e789.

-27 Monestier O, Brun C, Heu K, Passet B, Malhouroux M, Magnol L, Vilotte JL, Blanquet V: Ubiquitous Gasp1 overexpression in mice leads mainly to a hypermuscular phenotype. BMC Genomics 2012;13:541.

28 Perie L, Parente A, Brun C, Magnol L, Pelissier P, Blanquet V: Enhancement of C2C12 myoblast proliferation and differentiation by GASP-2, a myostatin inhibitor. Biochem Biophys Rep 2016;6:39-46.

29 Brandt C, Hansen RH, Hansen JB, Olsen CH, Galle P, Mandrup-Poulsen T, Gehl J, Pedersen BK, Hojman P: Over-expression of Follistatin-like 3 attenuates fat accumulation and improves insulin sensitivity in mice. Metabolism 2015;64:283-295.

-30 Gangopadhyay SS: Systemic administration of follistatin288 increases muscle mass and reduces fat accumulation in mice. Sci Rep 2013;3:2441.

-31 Brun C, Perie L, Baraige F, Vernus B, Bonnieu A, Blanquet V: Absence of hyperplasia in Gasp-1 overexpressing mice is dependent on myostatin up-regulation. Cell Physiol Biochem 2014;34:1241-1259.

-32 Magnol L, Monestier O, Vuillier-Devillers K, Wagner S, Cocquempot O, Chevallier MC, Blanquet V: A sensitised mutagenesis screen in the mouse to explore the bovine genome: study of muscle characteristics. Animal 2011;5:663-671.

33 Samuel VT, Shulman GI: Mechanisms for insulin resistance: common threads and missing links. Cell 2012;148:852-871.

-34 Hotamisligil GS, Arner P, Caro JF, Atkinson RL, Spiegelman BM: Increased adipose tissue expression of tumor necrosis factor-alpha in human obesity and insulin resistance. J Clin Invest 1995;95:2409-2415.

-35 Wang Y, Lam KS, Kraegen EW, Sweeney G, Zhang J, Tso AW, Chow WS, Wat NM, Xu JY, Hoo RL, Xu A: Lipocalin-2 is an inflammatory marker closely associated with obesity, insulin resistance, and hyperglycemia in humans. Clin Chem 2007;53:34-41.

-36 Juhan-Vague I, Alessi MC: PAI-1, obesity, insulin resistance and risk of cardiovascular events. Thromb 


\section{Cellular Physiology Cell Physiol Biochem 2017;44:1896-1911 and Biochemistry Publisheg \begin{tabular}{l|l} 
DOI: 10.1159/000485878 & $\begin{array}{l}\text { (c) } 2017 \text { The Author(s). Published by S. Karger AG, Basel } \\
\text { www.karger.com/cpb }\end{array}$
\end{tabular} \\ Périè et al.: Role of GASP-1 in Insulin Resistance Molecular Mechanisms}

Haemost 1997;78:656-660.

-37 Hill JJ, Qiu Y, Hewick RM, Wolfman NM: Regulation of myostatin in vivo by growth and differentiation factor-associated serum protein-1: a novel protein with protease inhibitor and follistatin domains. Mol Endocrinol 2003;17:1144-1154.

-38 Tamura Y, Kawao N, Yano M, Okada K, Matsuo O, Kaji H: Plasminogen activator inhibitor-1 deficiency ameliorates insulin resistance and hyperlipidemia but not bone loss in obese female mice. Endocrinology 2014;155:1708-1717.

-39 Hadad N, Burgazliev 0, Elgazar-Carmon V, Solomonov Y, Wueest S, Item F, Konrad D, Rudich A, Levy R: Induction of cytosolic phospholipase a2alpha is required for adipose neutrophil infiltration and hepatic insulin resistance early in the course of high-fat feeding. Diabetes 2013;62:3053-3063.

-40 Jonker JW, Suh JM, Atkins AR, Ahmadian M, Li P, Whyte J, He M, Juguilon H, Yin YQ, Phillips CT, Yu RT, Olefsky JM, Henry RR, Downes M, Evans RM: A PPARgamma-FGF1 axis is required for adaptive adipose remodelling and metabolic homeostasis. Nature 2012;485:391-394.

-41 Tanigaki K, Vongpatanasin W, Barrera JA, Atochin DN, Huang PL, Bonvini E, Shaul PW, Mineo C: C-reactive protein causes insulin resistance in mice through Fcgamma receptor IIB-mediated inhibition of skeletal muscle glucose delivery. Diabetes 2013;62:721-731.

-42 Araujo TG, Oliveira AG, Carvalho BM, Guadagnini D, Protzek AO, Carvalheira JB, Boschero AC, Saad MJ: Hepatocyte growth factor plays a key role in insulin resistance-associated compensatory mechanisms. Endocrinology 2012;153:5760-5769.

-43 Meissburger B, Stachorski L, Roder E, Rudofsky G, Wolfrum C: Tissue inhibitor of matrix metalloproteinase 1 (TIMP1) controls adipogenesis in obesity in mice and in humans. Diabetologia 2011;54:1468-1479.

44 Hittel DS, Axelson M, Sarna N, Shearer J, Huffman KM, Kraus WE: Myostatin decreases with aerobic exercise and associates with insulin resistance. Med Sci Sports Exerc 2010;42:2023-2029.

45 Takahashi H, Sato K, Yamaguchi T, Miyake M, Watanabe H, Nagasawa Y, Kitagawa E, Terada S, Urakawa M, Rose MT, McMahon CD, Watanabe K, Ohwada S, Gotoh T, Aso H: Myostatin alters glucose transporter-4 (GLUT4) expression in bovine skeletal muscles and myoblasts isolated from double-muscled (DM) and normal-muscled (NM) Japanese shorthorn cattle. Domest Anim Endocrinol 2014;48:62-68.

46 Mann N, Rosenzweig A: Can exercise teach us how to treat heart disease? Circulation 2012;126:2625-2635.

47 Dong J, Dong Y, Dong Y, Chen F, Mitch WE, Zhang L: Inhibition of myostatin in mice improves insulin sensitivity via irisin-mediated cross talk between muscle and adipose tissues. Int J Obes (Lond) 2016;40:434-442.

48 Shan T, Liang X, Bi P, Kuang S: Myostatin knockout drives browning of white adipose tissue through activating the AMPK-PGC1alpha-Fndc5 pathway in muscle. FASEB J 2013;27:1981-1989.

49 Lin J, Arnold HB, Della-Fera MA, Azain MJ, Hartzell DL, Baile CA: Myostatin knockout in mice increases myogenesis and decreases adipogenesis. Biochem Biophys Res Commun 2002;291:701-706.

50 Luquet S, Lopez-Soriano J, Holst D, Fredenrich A, Melki J, Rassoulzadegan M, Grimaldi PA: Peroxisome proliferator-activated receptor delta controls muscle development and oxidative capability. FASEB J 2003;17:2299-2301.

-51 Wang YX, Zhang CL, Yu RT, Cho HK, Nelson MC, Bayuga-Ocampo CR, Ham J, Kang H, Evans RM: Regulation of muscle fiber type and running endurance by PPARdelta. PLoS Biol 2004;2:e294.

52 Artaza JN, Singh R, Ferrini MG, Braga M, Tsao J, Gonzalez-Cadavid NF: Myostatin promotes a fibrotic phenotypic switch in multipotent C3H 10T1/2 cells without affecting their differentiation into myofibroblasts. J Endocrinol 2008;196:235-249.

53 Bouzakri K, Plomgaard P, Berney T, Donath MY, Pedersen BK, Halban PA: Bimodal effect on pancreatic beta-cells of secretory products from normal or insulin-resistant human skeletal muscle. Diabetes 2011;60:1111-1121.

-54 Okamoto Y, Folco EJ, Minami M, Wara AK, Feinberg MW, Sukhova GK, Colvin RA, Kihara S, Funahashi T, Luster AD, Libby P: Adiponectin inhibits the production of CXC receptor 3 chemokine ligands in macrophages and reduces T-lymphocyte recruitment in atherogenesis. Circ Res 2008;102:218-225.

-55 Harmon EB, Apelqvist AA, Smart NG, Gu X, Osborne DH, Kim SK: GDF11 modulates NGN3+ islet progenitor cell number and promotes beta-cell differentiation in pancreas development. Development 2004;131:6163-6174.

56 Koster JC, Remedi MS, Qiu H, Nichols CG, Hruz PW: HIV protease inhibitors acutely impair glucosestimulated insulin release. Diabetes 2003;52:1695-1700.

57 Walli R, Herfort O, Michl GM, Demant T, Jager H, Dieterle C, Bogner JR, Landgraf R, Goebel FD: Treatment with protease inhibitors associated with peripheral insulin resistance and impaired oral glucose tolerance in HIV-1-infected patients. AIDS 1998;12:F167-173. 